\title{
The WPA Guide to Renaissance Florence, or A Writer's Paradise
}

Los Angeles has usually needed water far too much to worry about what was in it. In 1939, though, the question becomes impossible to avoid: What was in the water? Raymond Chandler was stripping his pulp stories for parts to build his first novel, The Big Sleep. John Fante was mining his misery for Ask the Dust. F. Scott Fitzgerald was trying to stay on the wagon in Encino and mapping out The Last Tycoon. And Nathanael West was inventing film noir by day-hacking away at RKO B pictures like The Stranger on the Third Floor-and writing his masterpiece, The Day of the Locust, at night.

On the studio lot, Victor Fleming was cleaning up his betters' messes on both Gone With the Wind and The Wizard of Oz. Dalton Trumbo was working just as hard, climbing to the top of the screenwriter's pay scale and tossing off the great antiwar novel Johnny Got His Gun between assignments. And Orson Welles, like Los Angeles, was about to peak and didn't know it.

If only there were some record, some almanac of what it was like to walk those laughably walkable boulevards, to breathe that ludicrously perfumed air. If only some benevolent patron had stepped in and commissioned a panorama of prewar Los Angeles, so that future generations could enjoy it vicariously-maybe even try to replicate the freakish atmospheric conditions that made those masterworks possible. In other words, if only there existed the book that you, like a sleeper hoping vainly to drag some treasure back from dreamland, now hold in your hand.

On July 27, 1935, President Roosevelt had signed legislation authorizing the Federal Writers Project. The Project recognized that scribblers, no less than stonemasons and bridge builders, needed work. For any reader, the crowning glory of the New Deal will always be this and the other American Guides, a series of travel companions to 48 states, many cities, and any number of deserts, rivers, and other wonders-all created to "hold up a mirror to America." John Steinbeck navigated by 
the guides to write Travels With Charley, in which he called them "the most comprehensive account of the United States ever got together, and nothing since has even approached it."

The American Guide Series, in turn, was only one endeavor of the larger Federal Writers Project (FWP), which also turned out a raft of invaluable studies, including oral histories of freed slaves. The FWP, meanwhile, was but a single arm of Federal One, which also included the music, art, and theater projects that gave Orson Welles, among other artists, their biggest sandbox to date. And Federal One-stay with me here-was part of the Works Progress Administration (WPA), which belonged to a whole Scrabble rack of acronyms that came out of the New Deal. Finally, the New Deal was shorthand for all the programs devised to fight the Depression under the leadership of the most effective monogram of them all: FDR. He wrote this guide or nobody did.

To compile a well-organized guidebook to Los Angeles would be, of course, to misrepresent the city completely. Even a well-organized essay on the subject invites trouble. Neither attempt has been made here. The WPA guide to Los Angeles proceeds, sensibly enough, from I. Los Angeles: A General Survey, to II. Los Angeles Points of Interest, through III. Neighboring Cities, to, finally, IV. The Country Around Los Angeles. This has logic in its favor, but occasions a fair amount of unobjectionable repetition. The book develops more or less concentrically, like ripples in a tarn—or, to pick a more homegrown metaphor, like an earthquake.

This facsimile edition, Los Angeles in the I930s, is many books in one. (Not surprising, since it had dozens of contributors.) It's a guidebook, of course, complete with still-enjoyable walking and driving tours, restaurant and hotel recommendations, even species-specific hunting laws. (Perhaps atoning for I920s extermination of the state animal, the California grizzly, the California Department of Fish and Game apparently set a strict taking limit on the state bird: a mere ten California valley quail a day.)

The guide also qualifies as addictively readable history, with vivid accounts of L.A. under the flags of colonial Spain, Mexico, the fleeting California Republic, and, at last, the United States. And finally, no one thinks of it this way, but the WPA guide to Los Angeles is a compact coffee-table book of dazzling monochrome photography, with mostly (unlike the text) attributed contributions from the likes of Julius Shulman, Bret Weston, and the sadly unremembered Fred William Carter, about whom a bit more later.

But the guide may mesmerize most today as a set of elusive preconditions for a writer's paradise, a lost map to Shangri-La-an Eden kit. (The creator of Shangri-La himself, Lost Horizon author James Hilton, was even living in the vicinity, alternating underrated novels with over- 
rated screenplays.) Against all reason, I can't help thinking that somewhere within my first-edition copy must lurk the necessary recipe for this fleeting cocktail of genius, if we could only look closely enough to find it. Did the juice of a windfall orange drip off the original owner's chin, causing the fateful page to stick to its neighbor?

\section{HINDSIGHT}

Whatever the secret, it sure wasn't general prosperity. In the late 'zos, plenty of people still lacked even a room to go to bed hungry in. The Depression plays an oddly recessive role in these pages, usually referred to in the past tense but occasionally in the imperfect, as if not quite safely behind us. And an auto tour to Crystal Lake includes a fascinating if less than scenic side trip past "Hooverville, I $m$., now only a scattering of tattered tents and crude log shacks along the banks of the river between Susanna and Graveyard Canyons, but in the depression years 1930-33 a collection of 500-odd shacks, tents, and dugouts occupied by gold-seeking unemployed male transients" (p. 303).

When all else failed, this reflex to scratch a livelihood from the earth beat deep in the veins of Depression-era Angelenos-some of whom, even by 1938 , were still a few years older than the state in which they lived. The lazy production designer's temptation to think of the period as a sleek metropolis of '3os Packards tooling endlessly past Art Deco showplaces is even more absurd than expecting everyone in 2010 to carry an iPad. On the contrary, Angelenos of the I93os had ample reason to try and wring an extra few years' wear out of their pre-Depression hand-me-downs. One explanation for the crazy-quilt quality of the built environment was that, for want of money, few teardowns ever got torn down. Capital improvements would have to wait for more capital gains. For better and worse, I939 was the year in which a newly arrived Christopher Isherwood could miraculously confide to his diary, "We had an hour to spare, and we spent it finding an apartment."

So if material comfort wasn't the enzyme that catalyzed the class of I939, what was it? We can safely rule out good government, too. A brief entry in the guide's chronology for Sept. I6 of that year, reading "Special recall election ousts Mayor Frank L. Shaw, electing in his stead Fletcher Bowron," doesn't begin to plumb the depths of corrupt executive cluelessness into which the city had descended. "The sun is shining in Southern California and all is well," Shaw had proclaimed a few months earlier in a national radio address, as more than a hundred of his constituents lay freshly drowned around him.

A shaky case might be made that bad government inspires better storytelling than good. Shaw's kleptocracy and his police department's strong-arm tactics certainly kept both Raymond Chandler and Los Angeles 


\section{xxii A W R I T E R' S P A R A D I S E}

Times publisher Harry Chandler (no relation, damn it) well provisioned with material-by no means all of which made it into the paper. Pervasive amorality has never exactly discouraged the production of great creative work, especially dark work, or what's a Borgia for?

Fun though it may be to imagine Shaw and his cronies in the dock pleading, "I did it for art," this alibi ultimately doesn't wash. There are just too many counterexamples in history, too many badly governed regimes that generated little of lasting value beyond the cautionary. It's far likelier that Chandler and company variously rose above, hid out below, or plowed implacably along beside the petty distractions of municipal affairs. One hopes that they voted, though not necessarily that their candidates won.

If any single shared force impelled them, it may well have been rivalry - a mutual awareness of what good stuff the competition was turning out. The WPA guide lists no shortage of watering holes for the class of ' 39 to gather and goad each other in. Some of these establishments survive today, if not all at the same address or with remotely the same menu. Musso \& Frank endures, but Lucey's Cafe on Melrose has long since thrown over "Italian food in an atmosphere of quiet conservatism" in favor of Mexican cuisine with a picture of Jerry Brown in the window.

Still, any image of Chandler, Fitzgerald, and the rest knocking back postprandial highballs at Musso's, then adjourning to Stanley Rose's Bookshop for bouts of poker and one-upmanship, probably owes less to history than to their idolaters' forgivable wishful thinking. These were loners, most of them, asocial bordering on anti-. Fante and the great California historian Carey McWilliams genuinely loved each other, bonding over their shared Colorado origins. But little proof exists that their fellow Coloradoan Trumbo, for instance, ever shared a conversation, let alone a bottle, with his Five Came Back co-screenwriter Nathanael West.

The titans of prewar L.A. literature likelier coexisted as discretely as they do now on our bookshelves, rubbing shoulders then as glancingly as they do spines today. Had they been joiners, the hungrier among them might have found work in the Southern California Writers Project office, but only High Noon screenwriter Carl Foreman, among writers remembered today, ever answered the project's call. Look no further than Foreman for the author of this heartfelt, regrettably evergreen passage: "Strangely enough, despite their power and the lavish salaries that many of them receive, screen and radio scribes remain virtually anonymous to the general public, their names being overshadowed by those of the stars, producers, and directors." Glad that's all behind us.

For their solitude, the geography of Southern California met these writers more than halfway. Maybe we should be grateful that so many of them lived a ways apart, since more benders of opportunity might 
have cost us too much good work. At the publication of the WPA guide in I94I, perhaps the most ubiquitous symbol of Los Angeles mobility had only just extended its first, modest tendril from downtown to Pasadena-the Arroyo Seco Parkway, whose more common synonym freeway appears not once in its pages.

On the subject of absent landmarks, you could look in vain here for any mention of the region's most beautiful edifice, though it was already nearing its 5oth birthday. Designed by a correspondence-school architect who never again created anything approaching such weightlessly perfect loveliness, the Bradbury Building still hovers above the intersection of 3 rd and Broadway downtown today-just across the street from its cherished sidekick, the Grand Central Market, which the guide writes off a bit breezily as "the city's largest retail dispensary of perishable foodstuffs." For perishability, these editorial judgments have it all over any Grand Central Market produce.

On the subject of brand new architecture, strangely, the guide does a bit better. The year 1939 in Los Angeles wasn't just a great year for writers and books. It also marked the grand opening of the city's greatestever gift to itself, enacted I3 years earlier in a landslide over the ironically unified opposition of the Union and Southern Pacific and Santa Fe railroads. The Union Passenger Terminal, aka Union Station, opened its doors over a giddy three-day weekend in May of 1939, rating three thorough - if maddeningly underimpressed-paragraphs from the guide. Yes, it's "huge," but isn't it also exaltingly graceful? Yes, "the South Patio, with pepper, palm, and olive trees and trumpet and cup-of-gold vines, is intended to represent California planting and garden design at its best," but what else? Are those intentions, just maybe, spectacularly met and surpassed? And Union Station may actually consist of "30 low stuccoed, tile-roofed buildings," as the guide helpfully notes, but how do those components manage to convey the impression of one enormous, thrilling cathedral to the twin gods of luxury and motion? The reader moves on, informed if not quite edified.

Union stations, of course, are ten a penny. Chicago has one. So does St. Louis. California has another one just down the coast, in San Diego. All a "union station" means is a train station serving more than one railroad company. And in I930s Los Angeles, the name most certainly did not refer to the labor that created it.

Like the WPA guide to L.A., Los Angeles's Union Station is the work of many unremembered Depression-era hands. Also like the guide, this "Last of the Great Railway Stations" eclipsed expectations at first, only to lapse into disuse later. The shock of World War II became the guide's undoing, in part because few had the time or gasoline anymore for its sightseeing tours, yet the war proved the making of Union Station, through whose portals GIs poured in their hundreds of thousands. 


\section{xxiv A W R I T E R'S PARA DIS E}

By midcentury, red-baiting and tailfins had knocked both the Federal Writers Project and Union Station flat. Maybe only now, with the WPA guide to Los Angeles poised for republication, and Union Station the hub for a new multimodal, post-Hummer L.A., do both stand revealed as the quintessence of any great public works project: a bet on the future.

\section{FORESIGHT}

Did they know it wouldn't last? Could the artists we revere from L.A. circa 1940 have any inkling that the renaissance they were enjoying had less than a year to live? The question seems absurd, yet look at the masterpieces we cherish from those years. Forget, for a moment, the biographical quirks and crotchets that conspired to bring their creators to this idyllic, Edenic place and time. Imagine instead Gone With the Wind, Citizen Kane, The Wizard of $\mathrm{Oz}$, and the great novels of '39 as the work of a single undifferentiated imagination-a Los Angeles oversoul. What do they have in common?

Pretty plainly, they're all, to varying but unmistakable degrees, parables of a paradise gone to rot. In Gone With the Wind, what is Tara but Scarlett's ideal of how the world used to work, before that nasty war had to come along and spoil everything? What is Xanadu in Citizen Kane but Charlie Kane's grossly overscaled vision of his place in the world, before the unappeasability of his own appetites finally hollowed it out from under him? And what might $\mathrm{Oz}$ be, if not the emerald embodiment of Dorothy's fantasy life until her fever broke, collapsing it in an eyeblink like one vast iridescent soap bubble?

A plantation house. A pleasure dome. A literal dream city. Los Angeles circa 1940 was all of these-a precarious crystal palace, poised on a historical fault line between depression and war.

Solitary arts like fiction or painting may provide the best window into a singular artist's soul. (Marlowe is Chandler, or who Chandler fancied himself to be.) But sometimes it takes a communal art form to achieve a window on the world beyond the frame, even a premonition of that world's future. Movies can be one such collaborative art; guidebooks, at their best, are another. The WPA guide to Los Angeles doesn't make too many explicit predictions about the city, but when it does, an interesting thing happens: Its usually reliable fetish for detail falters, but its crystal ball sharpens into near clairvoyance.

Just look at the guide's entry on Los Angeles literature. None of the writers who made 1939 such an annus mirabilis gets so much as a look-in. In their place we hear about Zane Grey, Edgar Rice Burroughs, Hamlin Garland, and Will Rogers, about the creators of Philo Vance and 
Charlie Chan, and about Upton Sinclair, whose internationally bestselling Lanny Budd series began in I940-in some cases underestimated writers, but none of them grew up in L.A. or, more important, ever set a good book here. Nonetheless, the guide has matters almost exactly right when it says, "The outlook for the emergence of a distinctive regional literature seems favorable." The reasons cited, too, are right on the money: "unusual themes and varied natural settings; a stimulating and romantic history as well as a dynamic contemporary life; and endlessly varied people in process of amalgamation; a wealth of curious customs, peculiar religions, bizarre political movements, and changing social modes."

Blithely flanking those semicolons are, in fact, the exact four reasons L.A. soon became_-was already becoming, if only they'd noticed-home to a literature so rich that only a guide edited on the East Coast would dare call it regional:

"Unusual themes and varied natural settings." First position here, as in any discussion of L.A. writing outside the pages of the guide, goes to Chandler. Theme dictated setting for him, nowhere more so than in his first book, the most exquisitely location-managed novel the city had yet seen. To chart the hereditary corruption of the Sternwood fortune from first chapter to last, The Big Sleep burrows inexorably downhill from General Sternwood's mountaintop mansion to the sulfurous wrecked oilfield that underwrote it. When some anonymous WPA hand pauses to explain a diagonal oil drilling technique with the evocative name of "whipstocking" - "whereby wells are drilled at an acute angle to reach under the beach and sea" - any Chandler buff would recognize just the vector he means.

"A stimulating and romantic history as well as a dynamic contemporary life." It's hard to read a line like this today and not think immediately of historian Carey McWilliams. In I939's Factories in the Field, and in the earlier Southern California: An Island on the Land-still the definitive resource on L.A. history up through the '3os, and not a half-bad bellwether for everything that came after-McWilliams combined scrupulous history with bracing outrage at the injustices around him. The acknowledgment to McWilliams in the guide's preface among "the many individuals who volunteered their assistance in special fields" goes a long way toward explaining how the work of so many hands can feel suffused by a singular intelligence. Too many L.A. novelists haven't read him, but, know it or not, everybody in town they admire probably has.

"Endlessly varied people in process of amalgamation." A half century before overuse debased multiculturalism into a cliché, the WPA guide recognized L.A.'s potential as a seedbed for fine first- and second-generation immigrant literature. By no means immune from the odd blithe racist 


\section{Xxvi A W RITER'S PARA DIS E}

anachronism-Boyle Heights is described as "a section teeming with Jews and Mexicans" - the guide remains far too valuable to throw overboard for one or two linguistic indelicacies. It saw Oscar Zeta Acosta coming, even if it missed the likes of Carlos Bulosan under its very nose. For my part, as a descendant of those teeming Boyle Heights Jews and now one myself, I can live with it.

"A wealth of curious customs, peculiar religions, bizarre political movements, and changing social modes." This is Nathanael West's surreal side of the street. There's a whiff of carpetbagging condescension about L.A. here, but rueful Angelenos say as much and worse to themselves daily. There's no point in denying the carnivalesque side of L.A. life just because outsiders see little else. That's like avoiding the beach on a sunny December day, just so the folks back East won't think you shallow. The folks back East don't care. Half of them are down at the beach waiting for you.

To their credit as well, the guide's editors make room for The Day of the Locust in a brief bibliography of L.A. fiction, alongside the variously drier ink of P. G. Wodehouse's Laughing Gas, John O'Hara's Hope of Heaven, Helen Hunt Jackson's Ramona, Horace McCoy's I Should Have Stayed Home, and a dozen more books that make even those relative rarities look overexposed. Of pre-I939 literature, only Upton Sinclair's Oil!, which describes the process of wildcatting in Long Beach so lovingly that a reader gets to feeling he could almost bring in a well himself, is sadly absent from the guide's list.

Ultimately, then, it's a split decision. The guide rightly envisions a robust future for L.A. writing, but barely notices that it's already begun. "The emergence of a distinctive regional literature" is not only likely, as the guide predicts, it's emphatically under way — and the WPA guide to Los Angeles is a prime exemplar of it.

One more precondition exists for a writer's paradise, and Fred William Carter's picture of it can be found opposite page 319. Centered in direct sunlight stands what looks like a waist-high black metal sign reading, in white letters, LOS ANGELES PUBLIC LIBRARY: BORROW A BOOK TO READ IN THE PARK. Standing to the left is a giant fringed umbrella, the kind you might buy at a patio furniture store. Under it looks to be a checkout station, although, inspiringly, you can't see a librarian for all the patrons.

I like at least three other things about this picture. First, the seven or eight readers in it almost all have their backs to the photographermaybe because he's just holding a camera instead of something important, like a book. Second, the only man whose face you can almost see, you can't, because he's wearing a natty fedora. And finally, looming up behind them all is what has to be described as a jungle. Several sturdy trunks stretch up out of frame, and the lush, dark, impenetrable foliage 
A WRITER'S PARA D IS E Xxvii

reaches back down almost to the brick footpath. A toucan would not feel out of place. The caption reads, in its entirety, "PARASOL LIBRARY IN PERSHING SQUARE."

I don't say a parasol library is necessary to transform Los Angeles back into a writer's paradise. I merely say that at one time Los Angeles had a parasol library-three of them, in fact-and it was a writer's paradise. Today it has none and, despite many fine points, it is not a writer's paradise. As Chris Isherwood might have said, do the maths.

\section{YAHRZEIT}

What took the class of 1939 so long to arrive, and where did it race off to in such a hurry? Periclean Athens lasted a good 30 years, after all. The Pax Romana reigned for two centuries. The Italian Renaissance hung in for three. We've seen that it wasn't generalized easy living or enlightened public officialdom that enabled the greatest flowering of creative production that American storytelling has ever seen. What, then? Factoring out the inevitable contributions of happenstance, the smart money is on three time-honored sources of artistic inspiration: beauty, depression, and guilt.

We shouldn't forget that Southern California in the I930s was, to an even greater extent than it remains today, among the most beautiful natural settings on earth. The buttery sunlight, fragrant air, and crystalline vistas all conspired to make any curmudgeon doubly miserable. Essentially loving romantic relationships for Chandler, West, and Fitzgerald could only have added to their frustration. How else to exorcise this queasy sense of unearned happiness, if not in art?

To make matters worse, since 1929 the rest of America had been experiencing the desperation that should, in a just world, have been theirs to enjoy. Thanks in part to Hollywood, whose diversions the world now needed more than ever, Los Angeles claimed a higher standard of living than any American city had a right to. (L.A. had annexed Hollywood on Feb. 7, I9I0, just seven months before motion-picture production began there. This looks almost as suspicious as if the United States had annexed California the very week after the discovery of gold-which, incidentally, also happened.)

For writers lately arrived from colder climes, all those actors' pretty mouths needed words, and the great literary steeplechase was on. Either the industry wrote you checks directly, or its ravenous story-hunger helped underwrite the publishers who wrote you the checks instead. Los Angeles was a relative boomtown in the middle of a depression, and it drew writers like moths to a night shoot.

The guilt must have been delicious. While the folks back home scrimped and shivered, writers like West got paid handsomely to slum. 


\section{Xxviii A W R I T E R'S PAR A D I S E}

And if family guilt didn't get you, your old muse was surely casting reproachful looks your way. What to do but buckle down and write some good fiction on the side, at least until the war-or liquor, or luxury, or some other saboteur-blew it all sky high?

If the war hadn't come along and melted down the gravy train for scrap, could that golden year or two have dug in for the duration? Could Los Angeles literature, like Jack Benny, have stayed '39 forever? Unlikely. The sudden, successive deaths of Scott Fitzgerald and Nat West on December 2I and 22, I940, came as a hammer blow from which L.A. writing would take years to recover. Was West just a constitutionally calamitous driver, or was he actually hurrying back from Mexico toward his friend and mentor's funeral? Nobody could ever agree. Either way, I picture him getting the news over his car radioMotorola's recent gift to Californians everywhere. "Obscure Jazz Age chronicler dead," the announcer reads. West just locks eyes with his bride beside him in the passenger seat and floors it. After that bleak December, not until the heyday of Joan Didion would Southern California regain the kind of cultural moment that inspires nostalgia, or guidebooks worth savoring.

Los Angeles courts nostalgia, and punishes it. If there's a WPA guide to a more vanished American city, beats me what it is. L.A. is such a city of immigrants that most of its own name disappeared on the way here. My family lost an -owitz or two, but Los Angeles mislaid the whole rest of "El Pueblo de Nuestra Señora la Reina de Los Angeles de Porciuncula," and it's been traveling light ever since. If you don't like the weather in San Francisco, they say, just wait five minutes. If you don't like the architecture in Los Angeles, maybe give it ten. And if you love Los Angeles-love it to distraction, abjectly, like the sultriest of femme fatales - then you're begging for heartbreak.

There's a useful Yiddish word in this connection, one with no real English equivalent: yahrzeit. Atypically, it's not even a put-down. Yahrzeit-pronounced, more or less, "yart-site"-literally means "time of year," but it's come to signify any anniversary of a loved one's death. In our anniversary-happy society, when every news-crawl requires a roster of the day's trivial birthdays, without recourse to yahrzeit we still have no word for death's anniversary, let alone a ritual for it. But if we did, for L.A. writers it might entail the lighting of a yahrzeit candle every December for the lost promise of a sustained literary golden age.

We could second-guess the guide all day, of course. That's partly what it's good for. If all the American Guides did were to confirm our own opinions 70 years ahead of time, they might flatter us for a while, but pretty soon that would get old. Los Angeles in the rozos exists to preserve not just the memory of a great city, but also the attitudes round and about it - the received wisdom of the time, regardless of whether 
A WRITER's PARA D I E Xxix anyone in their right mind would receive that wisdom in anything like the same way today. Had the guide gotten Los Angeles inarguably right, we might as well have padlocked L.A. in I94I and all headed south. There's a WPA guide to San Diego, too.

Instead we're here, clinging to this gerrymandered, strangely bridleshaped metropolis despite its best periodic efforts to fling us clear. For fine company, now we have the WPA guide to Los Angeles back. Idea bin for historical novelists, iffy crib sheet for fact-checkers, God's gift to narrative historians, Los Angeles in the I93os is a wayback machine for retrophile Angelenos everywhere. If the past really is another country, this book is our passport to it. Leave a forwarding address, and turn the page.

David Kipen

Los Angeles, 20I0 
This page intentionally left blank 